\title{
CREATIVE RENOVATION OF THE BAIXA POMBALINA IN LISBON AND ITS HISTORICAL BACKGROUND
}

\author{
Luís MOREIRA PINTO ${ }^{1}$, Artur MENTEL ${ }^{2 *}$, Klaudyna WAWRYKA $^{3}$ \\ ${ }^{1}$ University of Beira Interior, Faculty of Architecture, Department of Civil Engineering and Architecture, \\ Calçada Fonte do Lameiro, 6201-001 Covilhã, Portugal \\ ${ }^{1}$ CITAD Research Center, Rua da Junqueira, 188-198, 1349-001 Lisbon, Portugal \\ 2, ${ }^{3}$ Silesian University of Technology, Faculty of Architecture, Department of Architecture \\ Akademicka str. 7, 44-100 Gliwice, Poland
}

Received 16 June 2017; accepted 3 November 2018

\begin{abstract}
The principal aim of this work is to prescribe creativity into the renovation and reconstruction process in architecture. This issue connects both petrified past and unknown future with the simple idea of preventing local heritage and Portuguese legacy. The field of our research and creative design will be the Rua da Madalena (Madalena Street) in Lisbon downtown - Baixa Pombalina. The case study and estimated results would serve as a prototype for more innovative thinking about renovation of urban tissue and buildings for similar examples. Following the latest economic trends, the rebirth of traditional forms of business and interest for local heritage, we will attempt to bound raw numbers with endless sources of our creative minds. This case study, presented in the Heritage versus Tourism Conference in Lisbon, in May 2016 would be a step-by-step, a "know-how" example for many streets with various ambient over the world. Hence, the architectural and aesthetic values would be presented first, mathematical marketing formula afterward. The equation would involve both tangible and intangible factors and would be our attempt to introduce creative thinking as a ground for concrete, visible consequences. Architecture is a field, where this attempt could succeed.
\end{abstract}

Keywords: architecture, earthquake, emotions, heritage, Lisbon, reconstruction, renovation, street, urban design, wooden construction.

\section{Introduction}

Let us close our eyes and only focus on what we feel. Emotions - positive, negative floating values that cannot be seen but definitely have strong impact on our tendencies and decisions. Even while reading next verses of this elaboration, emotions will take part in overall result of our impression. The character and complexity of emotions are individual for each person and is strongly connected with his creativity. Creation is indeed the language of emotion - emitting and absorbing at the same time. The main theme of this article would be to prescribe this

*Corresponding author. E-mail: arturmentelpolsl@gmail.com 
language from intangible values to the strict market rules. The process will be presented during renovation project of Rua da Madalena - one of the historical streets of Baixa Pombalina district in Lisbon. In the first part we will try to define its emotional and tangible resources connected with historical memories. Later on, we will present the case study of Rua da Madalena, where we use creativity to transmit intangible values into real actions. At the end we will attempt to calculate the real value of our action including "cultural factor" - the ratio based on emotions, individuality and common heritage. As a conclusion we will justify our thesis "creativity is the bridge between the eternal world of emotions and concrete real-time actions".

\section{Historical background}

To begin with, it would be reasonable to mention, that this part of the city - Baixa Pombalina - has a special experience in implementing an innovative reconstruction plan for the urban tissue after great disease. It was shortly after 1 st November 1755 , when over $80 \%$ of the engineering material (17 000 out of 20000 buildings) was devastated by three earthshocks, furthered by $6 \mathrm{~m}$ height tsunami and fires - during All Saints' tragic spectacle. It seems this was the beginning of 18th century secularization of Europe, when in 1759 Voltaire published his satire Candide - inspired by the "absence of God" during the Lisbon tragedy (Dynes, 2000). Heritage was lost and in the brief approach, the rebuild was a result of the rapid intervention of Sebastião José de Carvalho e Melo, 1st Marquis of Pombal (1699-1782) employing military architects of the Golden Age of John V of Portugal - Manuel da Maia (1677-1768) and Hungarian Carlos Mardel (1695-1763). It was within weeks when Pombal began preparations of the renewal. Despite the good intentions of United Kingdom, France and Spain, due to transportation problems, the first aid arrived just in February next year. Although relations between State and Church were tense, Church provided the first instant help. King's wish was to set up a monastery as a hospital for injured civilians, while a convent was converted into a military hospital. Priests were sent among the city to distribute food, medicine and sangria. Pombal had to create a triumvirate of his own ministers and provided them with administrative structure of 12 bounded magistrates to develop different districts of the city. The renovation has been framed in three-part stages.

First one, concerned a very detailed investigation of the remaining goods - shops, public service buildings, pensions, roads and barriers - all of them were carefully measured and listed. This has met following problems with property owning competitions, bad field working conditions (Brooks, 1994).

Second issue was to prevent people from disrupting urban space and raising huts, shacks and shanties outside the city walls. Within first six months after the disaster approximately 6000 wooden constructions were raised. Shelters were half-private initiative and inhabited also the Royal Family. The prominent aim was to provide the strict urban master plan as a cessation of Baixa district tendencies, where desperate owners started to rebuild their property rapidly and without any order. The decree was written on 30 December, 1755, forbidding inhabitants to build outside the walls. This was until 12 February, 1756 when public pressure forced Pombal to dismiss it. To prevent inflation, construction salaries, rents and the prices of construction materials were all frozen. 
Third question concerned financing the investment. Little of European nations provided their support in that matter, but the main source appeared to be in Brazilian diamonds and $4 \%$ tax raise for manufacturing and merchandising, raised by Pombal. Military authorities developed five strategies for recreating the urban heritage of Baixa for him. How to prevent the past while creating the future?

- Reconstruct the urban layout;

- Enlarge the street section of the previous option;

- Reduce the stories number up to 2;

- Relocate the entire urban complex;

- delete the remaining debris and change the "last medieval city" into the first modern one.

Against the organic structure, which would remind the people of the cruel nature, an orthogonal idea of Eugénie dos Santos was approved. He realigned 5 main avenues, crossed by seven small streets and connecting new Praça do Comércio and Rossio Square. Modernised Ruas Nobres' adjusted to carriages move, were provided with full commercial merchandise and bureaucratic facilities. Three of them were joining legacy squares, and the one most located to the East was called Rua da Magdalena. The street is the heritage in itself, as its name also recall the lost legacy of St. Madalena Church - one of dozen demolished relicts in 1755 .

The Figure 1 presents a comparison between the old, organic network of Baixa and the State after Eugénie dos Santos' renovation. This comparison let us see the significance of the place which was exposed during the renewal process. The red square defines the location of this place. The former name of the street - Calçada do Caldas - comes from the large classical mansion located today near the Largo Adelino Amaro da Costa. It was funded and then accommodated by João and Luís Rodrigues Caldas. They were connected with Jiménez family, a Castelhanan line, that settled down in Portugal in 1476. For this reason, the place was called also Terreirinho do Jiménez. Bela Vista (Porto Alegre) and São Vicente (Lisboa) later. The Jiménez Palace was dedicated into public under the invocation of Imaculada Conceição, whose authorization for worship was given on December 1, 1766. The Rua Madalena is the direct "descendent" of this importance and legacy. Calçada do Caldas is even now indicated with an extension of the street, in its center.

Let us now focus on the meaning of the street in itself. In the history of urban planning, the street was recognized only in terms of visible volumes and morphology, not as a field for behavioral and psychological actions. Especially this urban object, its impression is dependable on the architecture that lines it up. Hence the street quality, in many aspects, should be equivalent to the level of attached buildings which are served by e.g. Rua da Madalena. The reconstruction process is also a creative attempt to connect interior with the exterior by a similar authentic pattern.

The case of Rua da Madalena is special, as the users have the ability to digest many cultures in one place. However, this process can be really successful and pleasant when both conversing cultures remained their own identities and legacies. The increasing trend of local heritage builds up people identity (Illés, 2012). Our proposal for these potential areas is to improve so called brand of the place which would be a landmark in itself. The high quality of technical and esthetic aspects would lead better economical income.

Especially the Baixa downtown streets played important role in creating local social and business life - as each of them was dedicated to a different merchandise sector. 


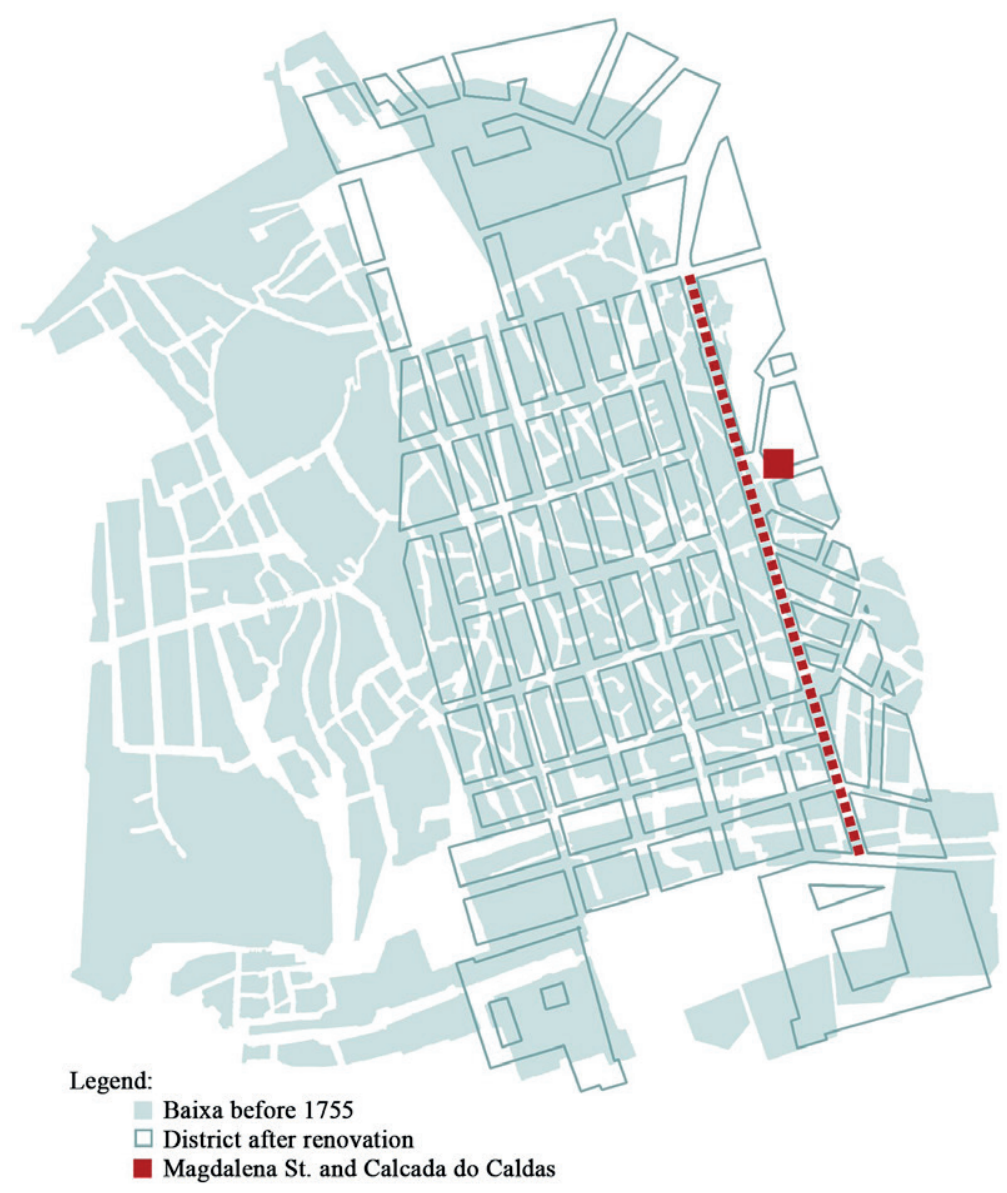

Figure 1. Comparison of Baixa district before the earthquake and after the renovation. Indication of Rua da Madalena in the city structure (source: authors' copyright)

The street al.o influences psychical profiles, memories and stories connected with the place and its ambient - these are postcards for future generations and the city in itself. The street layout has strongest impact on our general idea of the whole urban structure.

This is why a street - Rua da Madalena - becomes the label that attracts tourism industry and concrete income, hence our article demands methodology for research and systematic nomenclature for intangible, creative factors.

\section{Save the architecture legacy}

Restoration of the mutual historic zones of the urban space is essential in so called "place identity" politics. It was widely developed since the first project in Colonial Williamsburg in 1926 (Gay Holland, 2011, pp. 5-6). The basic cell - so called "component" - of the urban body is a quarter as an independent source of culture, gestures and human stories. The set of 
the several units, relations between them gives the true, direct sense of the city - an ambient (Kneafsey, 1998).

Marketing of the place, its image determines the concrete benefits from tourism, interest and correlation with different cities and improving the adopted politics for renovation or maintenance (Hu \& Herd, Forthcoming).

The social aspect of the street as a part of this quarter is the life in itself, the scene of our behavioral, economic and spiritual existence (Shaftoe, 2008). After the age of modernism however, the traditional meaning of the street has declined and became, what Richard Sennett called the "dead public space", most often "isolated and isolating" (Carmona, Tiesdell, Heath, \& Oc, 2010).

The subject of our renovation interest is Lisbon downtown street called Rua da Madalena. The first step of our research would attempt to delimit the area of renovation and if it is necessary? How can we use the creativity as a professional tool in dealing with economy, brand, marketing of the place? Creative not always means "brand new" - our project aim is to redefine the character of the place, transform the polluted, deserted space into the historical icon of the Baixa district.

Our interview beneath merchants and other occupants of the Rua Madalena provided one main conclusion, that the most needed intangible value in this area is authenticity and legacy feeling.

The concept connects unique brand with common, recognizable cultural language for Portugal, promoting national brands, home-made products, artisan food made by recipes from the 18th century, and Portuguese wine shops.

The creative approach is sometimes to use already existing motives in a brand new light. The main concept for Rua da Madalena is to reflect the original times, to adopt old rules into contemporary conditions, bring the future with the past.

In this way, the street will transform into the Rua da Madalena Wine Street, as we want to rebuild the original character of Baixa Pombalina in 18th century, when each street was responsible for certain domain of merchandise. Liquor tasting, selling, exposing, mixing specializing into the specific direction improves the character of the place. Because the creativity is also to bound many sites in a most simple, universal idea.

Statistics provided information, that young businessman and students demand a number of residential units, apartment for rent in this area. Social studies proved, that this is the preference of adult people before marriage and setting up their own family.

The street would become not only the "infrastructure beneath building units" (Gehl, 2011). I would get a tangible and an intangible value as well.

\section{The case study of Rua da Madalena in Lisbon, Portugal}

With 4 million tourists each night (for 2014) moving economy and the social life of the city the "extraordinary" feature increases, reported the president of Tourism of Portugal Minister, João Cotrim de Figueiredo. This number between 2012 and 2013 increased by $8.5 \%$. Such a tourist load is an extraordinary challenge to provide both economical income and preserve intangible legacy. 
After 1755 renovation, the Baixa layout was organized by themes, to indicate the transformation from "the last medieval city" to the "first modern" one. Hence such objects like Arco da Rua Augusta (Augusta Street), Rua Áurea (Gold Street) and Rua da Prata (Silver Street), or Rua dos Sapateiros (Shoemakers Street) were created. It became the merchant core of the capital.

Downtown borders the Tagus River, Rua do Carmo (Carmo Street), and Rua da Madalena at the same time. The marketing and selective branding is spread among the districts.

Nowadays the Rua Madalena is inhabited by various ethnic groups, selling random souvenirs in a low organized way.

Along the street line, two solid volumes run to the infinity. They are so called "gaiolas pombalinas" - 4 levels high tenement housing, from pragmatic period of renovation. They are recognizable by their unique anti-seismic construction, providing security in 3 dimensions and 1.5 meter piles dig in the ground. All bounded in the middle by representative staircase. This and other construction elements are joined with the Saint Andrew's Cross. That beauty coming from the necessity we all are looking for (Fonseca Teixeira, 2010).

It seems, that the significance of one building is indicated by the level of details in its ornament (Meireles \& Bento, 2010).

\subsection{Physical attributes}

Urban context of the place is extremely specific and already imposes its character. Firstly, it connects the historical Praça Martim Moniz (Square of Martim Moniz) the North and Alfândega Nova (Porto) the South. In the East, it is dominated by The Hill of São Jorge and the Moorish Castle. Praça Martim Moniz (Square of Martim Moniz) is the great parking support by underground. The Travessa da Madalena (Madalena Side Street), was one of the incubators of reconstruction in 1755. The name in itself comes from the existence of the Igreja de Santa Maria Madalena (Santa Maria Madalena Church) from 1164, sponsored by King Afonso Henriques nearby so called Cerca Moura (Moorish Wall) and previously the Ancient Roman temple dedicated also to the woman cult of Cybele - the Goddess Mother.

The Church however was rebuilt 1363. Approximately in 1600 partially collapsed during the cyclone. After the 1755, João Paulo designed the bounded motives of the Roman and Christian Temple and opened to the public on July 22 in 1783 - as usual these days on the Patron's Day.

Famous olisipograph (science about cultural, historical aspects of Lisbon) Luís Pastor de Macedo the previous name of the street would be "Rua do Arco de Na Sra da Consolação" (The Street of Our Lady of Consolation).

It was in 1841 when the first walk-site was built. These times in 1880s the general modernisation of "gaiolas pombalinas" took place. Nowadays it is necessary to rethink the general section of each street of Baixa and adapt it into traffic and social demands in a creative way.

\subsection{Social attributes}

Creativity is to paint in a different shades and tastes, compose with them. It seems, that the ethical diversity of Rua da Madalena with their various Asian products, should be redefined with the common aim and pattern, even by creating shoppers' association. 


\subsection{Economic activities}

The primal income source of the street which was the wine merchandise has already disappeared and moved to Arco da Rua Augusta, Praça do Comércio, and Santa Justa Lift (lift for sightseeing). Most of the existing gaiolas are restructured into wide variety level hotels and guest houses.

\subsection{The intangible value of the street}

In this phase we would attempt to combine these two materials as well as immaterial value in the mathematical formula (Kotler, 2002), this will estimate the market value of the place product. The intangible value cannot exist independently but in correlation with urban scale, cultural context and external space relations. The true sustainability comes only from the combination of these two accurate numbers and authentic, intentional factor (Reiter \& Marique, 2012). Strict economical market does not concise this factor. Silent numbers - so called "cultural factors" (Fcs) are related to emotions and psychological sciences. These silent numbers are actually subjective relations between costumer, seller and the environment - they are not the number in itself but "an added value" to the local brand. The analyze of the common market immobility value formula will help us understand the process: $\mathrm{V}=(\mathrm{Vt}$ (trade value) + $\mathrm{Cc}$ (construction cost) $+\mathrm{Cp}$ ( project cost $)+\mathrm{Ca}$ (administrative cost $)+\mathrm{Ctx}) \times(1+\mathrm{M})$.

When solving the above mentioned formula, the methodology and aspects analyzed onspot in Rua da Madalena are essential. We should include economical, functional, environmental context, as well as accessibility, communication nodes, etc. Most useful would also be the statistic made among most typical users of the street - in the number of 100 . Beneath everything we should add the architecture value aspect. Even though we cannot control these numbers, they do exist and would influence the true market value.

\section{Inquiry}

The very first step in our methodology is to set the anchor - to define the character of the existing architecture and relatively use innovation versus tradition. A creative product would be the fresh but not detached vision of the Rua da Madalena.

Architecture value divides the object into color, material, texture, proportions, general relation categories. We attempt to find the common layout, bounded with tradition and contemporary trends. Numbers and intangible values were the sculpting elements for creativity. In this case, the structural and functional aspect is flexible, as the Pombaline gaiolas worked as modernistic "free plan" rule - independently of the division walls.

In-spot investigation was rated in four different assumptions:

1. The residents of the street or neighborhood should participate in the evaluation of the project of architecture;

2. Local memory is necessary on a day-to-day basis;

3. Architecture is a work of art?;

4. That value should be given in an equity valuation, the questioned intangible aspects. 
Examined pedestrians could be divided into two main social groups. Half of the 100 interviewed people were at the age between 18 and 50, the rest of the stakeholders were above 65 years old. Those groups involved also special cases of people living on the place since childhood and being bounded in blood with the older examined users. In that way we let the real-life conditions influence our formula.

The favorable respond into the legacy continuation was rising with the age of the interviewed person - only 4 out of 50 elderly said "no" to the importance of heritage in the future. The second group - younger one - gave affirmative answer to the question about architecture as a work of art - in contrast to the other half off the examined.

The way to define "cultural factor" here was the percentage of answers to the specific question. The question was as followed: "how much would you value the building you are using as a seller/buyer in Rua da Madalena”. That creative way of examination would connect idea with concrete number formula.

The analysis of responders estimated the "cultural factor" as $20 \%$ among the elder group. In the youngster group between 18 and 30 years, legacy is important in the nowadays street life for $76 \%$ people, this indicate $5 \%$ concern and importance related to the intervention on the street where they inhabit. An average value from these two groups for our percentage factor would be $13 \%$.

The interview concerned "local memory" aspect as well. It was however mostly neglected among the interviewed people. The social opinion during the creative renovation process is essential, as it builds the future relation with the building.

The following elements of our formula have different meanings - for instance construction cost (Cc), project cost (Cp) and administrative cost (Ca). "Cultural factor" is the quantified added value, not stable but proportionally rising with other elements.

Regarding on the land costs, Fc depends on the random events if land is already covered with buildings or free. For example, if there are underground constructions, if there are fossils, or whether it was an important battle site. Otherwise, it will not apply proportionality (Fc). The example formula can be shaped as follows: $\mathrm{V}=((\mathrm{Vt}+\mathrm{Cc}+\mathrm{Cp}+\mathrm{Ca}+\mathrm{Ctx}) \times$ $(\mathrm{Fc})) \times(1+\mathrm{M})$. Fc in this case study of Rua da Madalena, is about $13 \%$.

\section{Conclusions}

Throughout the history the street was considered only as a linear element of urban design, joining buildings. There are diverse ambient and souls of the street regarding on shape, material, texture of the buildings and general urban structure. It is our privilege to have it around us and responsibility to modernize the street combining past and future. This is how creativity works, which can also be a source of income to the nation.

Rua da Madalena is the more special the more different cultures have opportunity to interact within its borders. Nevertheless, each of these nations tries to prevent their own legacy and memories left in their own country. The main responsibility is to find the border between integration and mufti-cultural undefined space. Today, one can observe the positive outcome of globalization. The meaning of local heritage and legacy passes with next generations with a different shape (Illés, 2012). We could promote a creative revitalization of old cities center, which are normally historical areas we can reproduce a tourism destination brand. 
What bounds all times and generations together is the simple intangible idea to follow. Creativity in this case is, one can say a steer of the ship that floats in a right direction, numbers and engineering data is our fuel that can bring you anywhere. With both of them bounded - we can travel to the stars. Creativity becomes the bridge between the eternal world of emotions and concrete real-time actions.

The Rua da Madalena has been a forgotten place, of which the ambient and structure was understood in a wrong way, related to stalls, criminal minorities and dirt. The neighborhood of high quality streets also improved this impression. It is almost certain, that the street should attract more tourists in a way that the other Baixa avenues do, it should be fitted into whole concept.

There is also no doubt that with this aim reached, Rua da Madalena will have an amazing offer for visitors as well as the local people - and for this we are supposed to rise both tangible and intangible values - so called Fc. But to operate in the untouchable values one needs to speak the creativity language.

\section{References}

Brooks, Ch. B. (1994). Disaster at Lisbon: The Great Earthquake of 1755. Long Beach, CA: Shangton Longley Press.

Carmona, M., Tiesdell, S., Heath, T., \& Oc, T. (2010). Public places - urban spaces: the dimensions of urban design. Amsterdam: Elsevier Ltd.

Dynes, R. R. (2000). The dialogue between Voltaire and Rousseau on the Lisbon Earthquake: the emergence of a social science view. International Journal of Mass Emergencies and Disasters, 18(1), 97-115.

Fonseca Teixeira, da M. J. (2010). Reabilitação de edifícios pombalinos. Análise experimental de paredes de frontal. Dissertação de Mestrado. Instituto Superior Técnico. Universidade Técnica de Lisboa. Retrieved from https://fenix.tecnico.ulisboa.pt/downloadFile/395142134654/FINAL\%2054961.pdf

Gay Holland, A. (2011). The reconstruction of historical buildings: a visitor and historical site study. VCU Scholars Compass. Retrieved from https://scholarscompass.vcu.edu/cgi/viewcontent. cgi?article $=3637 \&$ context $=$ etd

Gehl, J. (2011). Life between buildings: using public space. Washington, Covelo, London: Island Press.

Hu, Y.-W., \& Herd, R. (Forthcoming). Reforming civil service and public service units pensions in China. OECD Economics Department Working Paper. Paris: OECD.

Illés, P. (2012). (Re)defining regional images: visions, perspectives and rural places in context of intangible cultural heritage. In P. Illés, M. Kaaristo, M. Rennu, N. Koskihaara, E. Vass, \& S. Lillbroända-Annala (Eds.), Identities and the Production of Local Cultural Heritage. Retrieved from http://www.ethnosry.org/ www/wp-content/uploads/2012/09/Identities-and-the-Production-of-Local-Cultural-Heritage1.pdf

Kneafsey, M. (1998). Tourism and place identity: a case-study in Rural Ireland. Irish Geography, 31(2), 111-123. https://doi.org/10.1080/00750779809478623

Kotler, Ph. (2002). Marketing management, millenium edition. New Jersey: Pearson Custom Publishing.

Meireles, H. A., \& Bento, R. (2010, 30 August - 3 September). Cyclic behaviour of Pombalino "Frontal" Walls. Proceedings of the 14th European Conference on Earthquake Engineering (14ECEE). In 14th European Conference of Earthquake Engineering (pp. 1-8). Ohrid: Curran.

Reiter, S., \& Marique, A.-F. (2012). Toward low energy cities: a case study of the urban area of Liège. Journal of Industrial Ecology, 16(6), 829-838. https://doi.org/10.1111/j.1530-9290.2012.00533.x

Shaftoe, H. (2008). Convivial urban spaces: creating effective public places. London, Sterling, VA: Earthscan. 


\title{
BAIKSOS POMBALINOS SENAMIESČIO LISABONOJE KÜRYBINĖ RENOVACIJA IR JOS ISTORINIAI PAGRINDAI
}

\author{
Luís MOREIRA PINTO, Artur MENTEL, Klaudyna WAWRYKA
}

\begin{abstract}
Santrauka
Pagrindinis šio tyrimo tikslas - apčiuopti kūrybiškumą architektūros renovavimo ir rekonstravimo procese. Šiame straipsnyje tiek sustabarèjusi praeitis, tiek nežinoma ateitis susiejama su paprasta ideja atmesti vietos paveldą ir portugališkąji palikimą. Mūsų tyrimo ir kūrybinio projektavimo sritis - Rua da Madalena (Madalenos gatvè), esanti Lisabonos senamiestyje - Baiksoje Pombalinoje. Atvejo tyrimas ir vertinimo rezultatai bus kaip novatoriškesnio mąstymo apie miesto audinio ir pastatų renovavimą, turint mintyje panašius pavyzdžius, prototipas. Atsižvelgdami ị naujausias ekonomikos tendencijas, tradicinių verslo formų atgimimą ir susidoméjimą vietos paveldu, sieksime susieti neapdorotus skaičius su begaliniais mūsų kūrybiško proto šaltiniais. Šis atvejo tyrimas, 2016 metų gegužę pristatytas Paveldo versus turizmo konferencijoje Lisabonoje, bus laipsniškas praktinès patirties pavyzdys daugeliui skirtingos aplinkos gatvių visame pasaulyje. Taigi pirmiausia bus pristatytos architektūrinè ir estetinè vertès, vèliau matematinès rinkodaros formulè. Lygtis apims tiek apčiuopiamus, tiek neapčiuopiamus veiksnius, ir tai bus mūsų pastangos remtis kūrybiniu mąstymu kaip konkrečių, matomų rezultatų pagrindu. Architektūra - tai sritis, kurioje šios pastangos gali būti sèkmingos.
\end{abstract}

Reikšminiai žodžiai: architektūra, žemès drebejjimas, emocijos, paveldas, Lisabona, rekonstrukcija, renovacija, gatvè, miesto projektavimas, medinè konstrukcija. 